\title{
Humble thanks to a gentle giant (an obituary for James F. Crow)
}

\author{
Daniel Gianola ${ }^{1,2,3}$, Guilherme J. M. Rosa ${ }^{1,2}$ and David B. Allison ${ }^{4 *}$ \\ 1 Department of Animal Sciences, University of Wisconsin, Madison, WI, USA \\ 2 Department of Biostatistics and Medical Informatics, University of Wisconsin, Madison, WI, USA \\ ${ }^{3}$ Department of Dairy Science, University of Wisconsin, Madison, WI, USA \\ ${ }^{4}$ Nutrition Obesity Research Center, University of Alabama at Birmingham, Birmingham, AL, USA \\ *Correspondence: dallison@uab.edu
}

A tribute to Jim Crow - genetics giant and generous, gentle man January 18, 1916January 4, 2012

When James Crow passed away last January at the age of 95, genetics lost one of its pre-eminent pioneers. One month before Professor Crow's death, the journal Genetics launched a series of articles honoring him. In an introductory editorial, Michael Turelli and Charles Langley referred to Professor Crow as "a living link between our generations and the founders of population genetics," and enumerated the varied areas in which Professor Crow's influence changed current thinking, including, "estimates of mutation rates, the evolutionary consequences of deleterious mutations, the evolution and maintenance of sexual reproduction and recombination, the mathematics and implications of genetic drift (including the neutral theory of molecular evolution), the genetics of departures from Mendelian segregation, and the genetics and evolution of insecticide resistance" (Turelli and Langley, 2011).

Owing to Professor Crow's longevity, the field of genetics, and more specifically the field of population genetics, was the grateful recipient of the fruits of his work for some 70 years. He was a key contributor to our deepest thinking and understanding on both theoretical and applied aspects of genetics, and his excellent work in population genetics models ranged from Drosophila (fruit flies) through livestock to humans.

Dan Gianola's Recollection: I audited Professor Crow's population genetics course in the summer of 1971, when I was a first-year graduate student. I did not dare to take the course for credit until I was almost finishing my Ph.D. thesis, though. Of course, I never suspected that we would become colleagues in Madison. In the 1971 version of the course, he made a statement about the remarkable stabil- ity of heritability estimates: given a trait, most estimates would cluster around some value, with only rare exceptions. I raised my hand, and said that one exception was heritability of fleece weight in sheep, where estimates from the Romney Marsh breed tended to be much lower than in Merino. After class, Jim came to me, and wanted to know more about Romney Marsh sheep, which are prevalent in New Zealand!

Professor Crow was born in Phoenixville, Pennsylvania, received his bachelor's degree from Friends University in Kansas, and earned his doctorate in zoology from the University of Texas in Austin. He worked at Dartmouth College for several years, and then joined the University of WisconsinMadison faculty in 1948, where he spent the next 64 years (Wade, 2012).

Over his career, Professor Crow authored hundreds of articles and books, covering such diverse topics as the genetic effects of radiation, variations in natural populations, sex determination, plant and animal breeding, transposable elements, the impact of mutations on populations, and the genetics of pesticide resistance (Sakai, 2012).

"He was an inspiring and stimulating person," said Professor Crow's longtime friend and collaborator, Rayla Temin, Ph.D., Adjunct Professor Emeritus of Genetics at the University of Wisconsin-Madison. She completed her Ph.D. under Professor Crow in 1963. "When you were in his presence, he made you happy just to be in the aura he cast” (Sakai, 2012).

David Allison's Recollection: Having followed his career as I traveled my own path in the field of statistical genetics, and having had the delightful opportunity to share a bit of time with him, two things are most prominent in my memory of Professor Crow. First, his penetrating acumen remains the equal of anyone I have met, and second, no one of his stature could be more gracious, self-effacing, or down-to-earth. Professor Crow was an extraordinarily gifted lecturer. He is renowned as teacher and mentor of young scholars ranging from undergraduate students to advanced post-doctoral fellows. I was honored to attend a meeting where Professor Crow was the keynote speaker. At a reception that evening, Professor Crow was surrounded by awed students and scientists, myself included, who listened spell-bound and enraptured by his tales of famous scientists, scientific eurekas, and his equally insightful comments on the discoveries of today.

Despite his gentle nature, Professor Crow never hesitated to speak his mind when his ideas were counter to popular thinking, even in his later years. His final paper was entitled "Upsetting the Dogma: Germline Selection in Human Males."

Professor Crow "retired" in 1986, but was not content to settle back and relax. He remained active in the genetics and evolution communities, and was still a popular speaker and contributor at campus seminars (Sakai, 2012). An accomplished musician, he had played the viola with the Madison Symphony Orchestra for more than 40 years (Moe, 2012), and on his 90th birthday, he began giving annual viola recitals for the Genetics Department (Figure 1). According to Millard Susman, Professor Emeritus of Genetics at the University of Wisconsin-Madison, "Jim aged, but he never stopped learning or thinking." Two weeks before he died, he was in his campus office, working on a new paper (Sakai, 2012).

Professor Crow received many honors and awards. The aforementioned series of articles in Genetics is continuing. He was awarded the Genetics Society of America Thomas Hunt Morgan Award for lifetime contributions to the field of genetics as well as numerous other lifetime achievement 


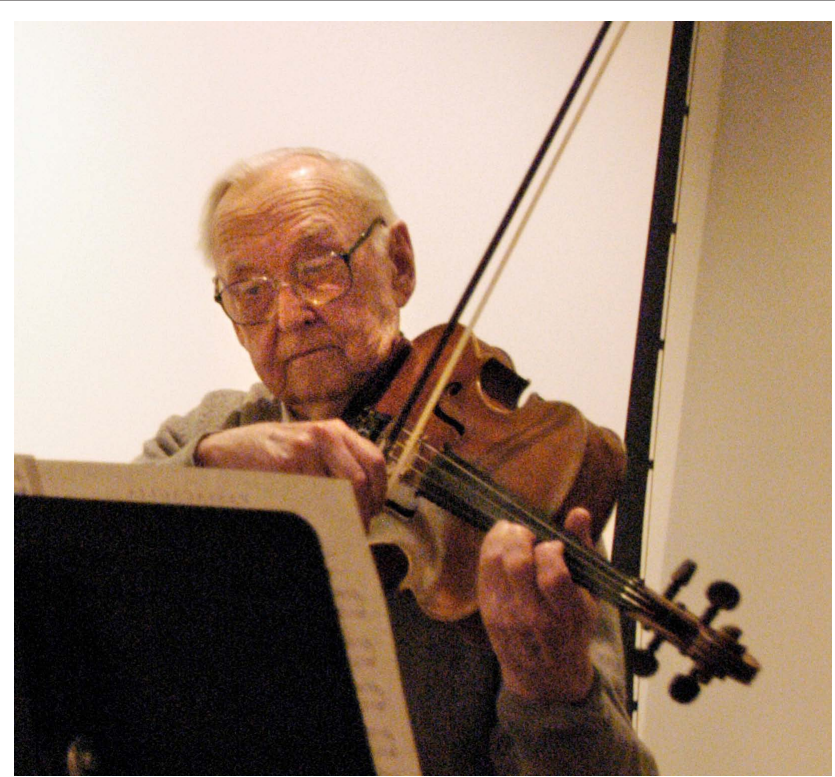

FIGURE 1 | Professor Crow, playing his viola on his 90th birthday (Photo courtesy of Jeff Miller, University of Wisconsin-Madison).

awards. He served as an officer or committee member of many professional organizations, and was a sought-after chairperson for national advisory and review committees. His memberships in the National Academy of Sciences, the National Institute of Medicine, the American Philosophical Society, the American Academy of Arts and Sciences, the World Academy of Art and Science, the Japan Academy, the Royal Society, and numerous other national and international professional societies attest to his extraordinary scientific productivity (Sakai, 2012).

In 2010, the University of Wisconsin began the James F. Crow Institute for the Study of Evolution, a cross-college institute supported by the College of Agricultural and Life Science, College of Letters and Science, School of Veterinary Medicine, School of Education, and Laboratory of Genetics (Sakai, 2012). Professor Crow had envisioned that the institute should be named for Sewall Wright, who had been important to Professor Crow himself and who forms a major part of the legacy of genetics and evolution; however, the future institute's members insisted instead to name the new entity in honor of Professor Crow (Hawks, 2012).

As accomplished as he was, Crow was gentle, gracious, and self-effacing. "He was a true gentleman in every sense of the word," says University of Wisconsin-Madison Professor of Genetics Barry Ganetzky. "I never heard him raise his voice or criticize anybody. He had the most positive outlook on life" (Sakai, 2012).

Guilherme Rosa's Recollection: I first met Jim Crow in 1997, when I came to UW-Madison as a visiting Ph.D. student. A big group of us were dining together, and I was surprised when Jim Crow sat beside me. He started talking to me, and as soon as he learned I was from Brazil (I think he quickly recognized my accent), he told me he had a close friend from Brazil, with whom he had lost contact. He was referring to Dr. Warwick E. Kerr, a former professor at the University of Sao Paulo, Brazil, who had worked with Jim Crow many years earlier, and later went to the University of Chicago. One of Jim's comments about Dr. Kerr was that sadly, although he was a top-notch geneticist of international caliber, he ended up being best known by the accidental release of African bees on the American continent. As a beekeeper myself during my high school and college years in Brazil, I knew that story quite well, so Jim Crow and I had material for some interesting conversation during that dinner.

Professor Crow's generosity with his time was an important element of his teaching and working relationships. A dedicated advisor and mentor, he was genuinely concerned about his students and collaborators alike. Colleague and former student Dr. Temin said, "When you were with him, he made you feel like you were the most important person at that moment" (Sakai, 2012).

Daniel Hartl, Higgins Professor of Biology at Harvard University, studied under Professor Crow. In 2000, he interviewed Professor Crow for a project called "Conversations in Genetics: An Oral History of Our Intellectual Heritage in Genetics," produced by Esposito (2000) and published on DVD by the Genetics Society of America. Dr. Hartl asked Professor Crow what he thought his legacy would be. Not surprisingly, Professor Crow's thoughts went to his students and colleagues: "If I have a legacy," he mused, "part of it is the collaborative work that I've done with other people." Then he continued: "But I want to say that part of my legacy is students. I've had an unusually good group of graduate students and postdocs, many of which have gone on to make names for themselves in genetics, and I like to think of that as my real legacy."

In a note appended to Crow's (2012) final article, Dr. Bret Payseur, Assistant Professor of Medical Genetics at the University of Wisconsin-Madison wrote: "Jim Crow passed away shortly after he finished writing this piece. Jim's infectious engagement with science lasted his entire life. This commentary marks the end of a storied career of research, teaching, and service that visibly advanced the field of population genetics. Jim considered the training of his many remarkable students to be his greatest gift to science."

On behalf of the scientific community, thank you, Professor Crow.

\section{ACKNOWLEDGMENT}

The authors would like to thank Ms. Catherine B. Galloway for assisting with preparation of the manuscript.

\section{REFERENCES}

Crow, J. F. (2012). Upsetting the dogma: germline selection in human males. PLoS Genet. 8, e1002535. doi: 10.1371/journal.pgen.1002535

Esposito, R. E. (2000). “Conversations in genetics: an oral history of our intellectual heritage," in Genetics, Vol. 2 (Bethesda, MD: The Genetics Society of America), ISBN 978-193320309-6.

Hawks, J. (2012). James F. Crow, 1916-2012. John Hawks Weblog, Wed, 2012-01-04 23:23. Available at: http:// johnhawks.net/weblog/topics/history/genetics/ james-f-crow-1916-2012.html 
Moe, D. (2012). Famous geneticist James Crow remained engaged until his death at 95. Wis. State J. [accessed January 15, 2012].

Sakai, J. (2012). UW Geneticist James Crow Passes Away. News from UW-Madison. Madison, WI: University of Wisconsin-Madison, University Communications.

Turelli, M., and Langley, C. (2011). Honoring our colleague James F. Crow, an outstanding gentleman, citizen, and scientist. Genetics 189, 1127.
Wade, N. (2012). James F. Crow, population genetics pioneer, dies at 95. The New York Times, Jan 10, 2012.

Received: 03 May 2012; accepted: 08 May 2012; published online: 04 June 2012.

Citation: Gianola D, Rosa GJM and Allison DB

(2012) Humble thanks to a gentle giant (an obituary

for James F. Crow). Front. Gene. 3:93. doi: 10.3389/ fgene.2012.00093
This article was submitted to Frontiers in Evolutionary and Population Genetics, a specialty of Frontiers in Genetics.

Copyright (c) 2012 Gianola, Rosa and Allison. This is an open-access article distributed under the terms of the Creative Commons Attribution Non Commercial License, which permits non-commercial use, distribution, and reproduction in other forums, provided the original authors and source are credited. 